\title{
Consumers' attitudes towards purchase intention for local brand automobiles manufactured in Malaysia
}

\author{
Anyanwu Hilary Chinedua, Sharifah Azizah Haron ${ }^{a, b^{*}}$, Ahmad Hariza Hashim ${ }^{a}$ and Jo Ann Ho
}

${ }^{a}$ Department of Resource management and Consumer Studies, Faculty of Human Ecology, Universiti Putra Malaysia, Serdang Selangor, Malaysia

${ }^{b}$ Malaysian Research Institute on Aging (MyAgeing $\left.{ }^{T M}\right)$, Universiti Putra Malaysia, Serdang Selangor, Malaysia

${ }^{c}$ School of Business and Economics, Universiti Putra Malaysia, Serdang Selangor, Malaysia

\section{CH R O N I C L E}

\section{Article history:}

Received: September 18, 2020

Received in revised format:

November 182020

Accepted: December 12, 2020

Available online:

December 12, 2020

\section{Keywords:}

Attitude towards local brands

Locally manufactured automobiles

Consumer ethnocentrism

Collectivism

Moral foundation theory

Proton automobile

Malaysia

\section{A B S T R A C T}

The damaging effects of market globalization towards developing countries necessitate the exhibition of favorable attitudes towards purchase intention for local brand automobiles manufactured locally. With the application of moral foundation theory (MFT), a quantitative and cross-sectional study that involved 373 Proton potential consumers through a mall intercept survey in Malaysia was analyzed. The results show that Proton's potential consumers had favorable attitudes towards purchase intention for Proton automobiles. Subsequent to a high mean score of collectivism and a moderate mean score of ethnocentrism, Proton potential consumers' ethnocentric tendency offers a contradiction to extant literatures on consumer ethnocentrism in developing countries. Thus, our study posits that consumers from collectivistic societies are ethnocentric and further display favorable attitudes towards local products. Additionally, the predictive effects of consumer ethnocentrism and collectivism on attitudes towards purchase intention for local brand automobiles manufactured locally were ascertained. Our findings validated the applicability of MFT in explaining consumers' attitudes towards local products. Other implications are also discussed.

\section{Introduction}

Market globalization, a significant surge in the movement of products across national borders has been witnessed greatly (Makanyeza \& Du Toit, 2017; Teo, Mohamad, \& Ramayah, 2011; Ranjbarian, Morteza, \& Mirzaei, 2010). It has particularly led to broader accessibility of products for provincial consumers (Lotz \& Hu, 2001). Liberalization and uniformity of markets increase concerns about the damaging effects of the inflow of imported products and/or brands on local production and employment (Samiee, 1994). Thus, it has presented both opportunities to marketers and generated some challenges (Ranjbarian et al., 2010). For instance, market globalization has depleted some economies due to consumers' unfavorable attitudes towards locally manufactured products (Chinedu, Haron, Hashim, \& Ho, 2020). Given this, it is crucial to understand and acquaint marketers especially local ones with factors that affect consumers' attitudes towards local products manufactured locally. To mitigate negative attitudes towards local products due to their deleterious effects on local economies, favorable attitudes towards purchase intention for local products should be sought via established elements of attitudes. Consumers' attitudes towards purchase intention for local/foreign products can be affected by consumer ethnocentrism (Karoui \& Khemakhem, 2019; Yildiz, Heitz-Spahn \& Belaud, 2018; Kumar, Fairhurst \& Kim, 2011), and collectivism (Chinedu et al., 2020; Sreen, Purbey, \& Sadarangani, 2018; Kumar, Fairhurst \& Kim, 2013). It is also believed to be affected by consumers' interest in

\footnotetext{
* Corresponding author.

E-mail address: sh.azizah@upm.edu.my (S. A. Haron) 
deriving joy and utility from local products which is demonstrated through individual attitudinal statements towards purchase intention for local products.

In essence, while favorable attitudes towards purchase intention for local products/local brand preferences are sought in varying degrees and different contexts (cf. Correa \& Parente-Laverde, 2017; Kumar et al., 2011; Saffu, Walker, \& Mazurek, 2010). Research has shown that consumers' favorable attitudes towards local brand automobiles manufactured locally reinvigorate local economies (Chinedu et al., 2020). Hence, favorable attitudes towards purchase intention for local brand automobiles manufactured locally are believed to beget a thriving economy due to financial marketing activities that ensue favorable consumer attitudes. Thus, the study attempts to answer the following questions: (i) Do consumers' attitudinal statements depict favorable attitudes towards local brand automobiles manufactured locally? (ii) What are the predictive effects of consumer ethnocentrism, and collectivism on attitudes towards purchase intention for local brand automobiles manufactured locally?

\subsection{Theoretical background}

Moral Foundation Theory (MFT) (Graham, Haidt, Koleva, Motyl, Iyer, Wojcik, \& Ditto, 2013) is a five-dimensional model based on intuitive ethics that bothers on the human inclination to care/harm, fairness/cheating, loyalty/betrayal, authority/subversion, and sanctity/degradation. According to Haidt (2012), these dimensions of MFT are predicated on original triggers and current triggers. Original triggers are associated with proper causes of any of the dimensions of MFT from inception, while current triggers refer to rebounds from negative relational experiences. Care refers to human beings' response to adaptive challenges of vulnerable offspring for an extended period (Graham et al., 2013), while harm is a form of gossip deliberations centered on ethical assessments of a third party's actions in their absence (Dunbar, 1996). Fairness/cheating bothers on the ability to be fair in relationships or short-changing a party in a relational exchange (Graham et al., 2013). People with advanced minds of eventual cheating before experiencing cheating sensitize relationships and reacts with emotions that coerce them into "tit for tat" (Trivers, 1971). Continuing, Loyalty/betrayal reveals the level of alliance or contests for survival between several creatures. Graham et al. (2013) note that people with advanced-organized sensibilities before experiencing competitions formed synergistic coalitions and became part of winning teams in such competitions. Authority/subversion on the other hand focuses on the living pattern of primates in pursuit of dominance hierarchies. Those whose minds are designed for eventual betrayal before practical experience are never short-changed in complex social interactions (De Waal, 1982; Fiske, 1991). In line with human pursuit for dominance hierarchies, compliance may be seen as an important virtue in social conservative cultures while it can be regarded as neutral or even as badness in social liberal cultures (Stenner, 2005). Lastly, Sanctity/degradation refers to how people that respect their bodies are praised in some cultures for the virtues of restraint and chastity, and/or the level at which people that have no respect for their bodies are repugnant in a society (Graham et al., 2013).

Of the five dimensions of Moral Foundation Theory (MFT), Care/harm, loyalty/betrayal, and sanctity/degradation dimensions were adopted to further explain attitude towards purchase intention for local brand automobiles manufactured locally and its elements. Predicated on MFT, we argue that attitude towards purchase intention for local brand automobiles manufactured locally is triggered by consumers' sensitivity towards perceived harm, betrayal, and degradation against their society/environment via favorable attitudes towards foreign brand automobiles. Vulnerable beings (infant indigenous companies) are dependent on ethnocentric consumers whose natural love and patronage for indigenous automobile manufacturing companies are demonstrated to lift them out of precarious market competitions. Ethnocentric consumers engage in chinwag discussions on the ethicality of the attitudes of non-ethnocentric consumers (Dunbar, 1996), with all these being triggered by moral emotions rather than private experiences (Graham et al., 2013).

Notably, in the build-up to favorable attitudes towards purchase intention for local brand automobiles manufactured locally, consumers will form groups (in-group and out-groups). To actualize a progressive in-group, harmony ought to be maintained and transgression of in-group norms leads to shame (Hofstede, 2011). We contend that collectivistic consumers establish prejudice against imported automobiles due to an increased level of market globalization in competition for larger market share. Collectivistic consumers are in other words loyal to their governments through their support to the local economy. They form synergistic coalitions and support local automobile companies by rising against market globalization. Success in this regard is characterized by group pride and vice versa.

Consumers' ability to exhibit favorable attitudes towards purchase intention for local brand automobiles manufactured locally is also morally linked to the sanctity of their environment/marketplace. While unnecessary foreign product influx is disgusting among ethnocentric and collectivistic consumers, the emotion of disgust against the degradation of local market is generally believed to be a modification to powerful adaptive challenge (Oaten, Stevenson, \& Case, 2009). Disgust against imported automobiles and favorable attitudes towards purchase intention for local brand automobiles manufactured locally is the guiding ethos of consumers' moral reactions. Under favorable attitudes towards purchase intention for local brand automobiles manufactured locally, consumers detest flooding of their markets with foreign automobiles which constitutes degradation to their market. They also perceive inundating their markets with imported brands at the detriment of local brands as dangerous competitions which amount to betrayal, and potential harm to their local economy. Hence, ethnocentric and collectivistic consumers display "tit for tat" emotions against perceived injurious acts towards local companies. 


\section{Literature review}

Consumer attitude towards an object or action is a product of behavioral beliefs and outcome evaluations (Ajzen, 1991; Fishbein \& Ajzen, 1975). Attitude is a combination of a consumer's beliefs, feelings, and behavioral intentions toward some products within a market (Perner, 2010), and has been shown to impact the final action of consumers in marketing activities (Fazio, Powell, \& William, 1989). Consumers exhibit various attitudes towards a product or brand based on different circumstances (Makanyeza, 2014). For instance, consumers opt for luxurious and expensive products to signal wealth or societal status (Vijayakumar \& Brezinova, 2012). Consumers from highly industrialized nations (Europe and North America) are favorably disposed to locally manufactured products (Verlegh, Jan-Benedict, \& Steenkamp, 1997; Samiee, 1994; Bilkey \& Nes, 1982), while those from developing countries such as Mozambique (John \& Brady, 2011), and Tunisia (Samoui, 2009) are favorably disposed to foreign brands in pursuit of social status. This reinforces the notion that consumers' attitudes hinge on issues that are central to them. In line with this and extant studies, we argue that a favorable attitude towards purchase intention for local brand automobiles manufactured locally is triggered by consumer ethnocentrism and collectivism. Therefore, it is imperative to review the connection between these two constructs and attitudes towards purchase intention for local brand automobiles.

\subsection{Consumer ethnocentrism and attitudes towards purchase intention for local brand automobiles manufactured locally}

Consumer ethnocentrism (CE) is a general tendency to avoid buying foreign products to avoid harm to the local economy, including an increase in unemployment which is unpatriotic (Shimp \& Sharma, 1987). CE was derived from the broad concept of ethnocentrism (Shimp, 1984), which is a sociological construct introduced by Graham Sumner in 1906 that implies one's group seen as central to everything and to reject persons who are dissimilar to their beliefs. Existing studies (Karoui \& Khemakhem, 2019; Yildiz et al., 2018; Kumar et al., 2011; Saffu et al., 2010) support a positive correlation between CE and consumer preference for local/domestic products and a willingness to buy domestic products. Consumer ethnocentrism transforms into consumers' preference for local products (Vida, Dmitrovic, \& Obadia, 2008; Cicic, Brkic, \& Praso-Krumpalija, 2003), and onward purchase intention. CE reduces consumers' intentions to purchase imported products (Vida et al., 2008; Klein, Ettenson, \& Krishnan, 2006) and increases preference for local brand preference (Kumar et al., 2011).

The level of ethnocentrism may differ from one country to another (Besic, 2017; Lantz \& Loeb, 1996); from a particular province to another within the same country (Shimp \& Sharma, 1987) and from one consumer to another (Vida \& Fairhurst, 1999). It may also vary based on a consumer's means and a place of livelihood (Yildiz et al., 2018). This implies that consumer ethnocentrism varies across individual and societal beliefs based on the technological superiority of societies. For example, consumer ethnocentrism is stronger in developed countries more than developing countries (Tsai, Lee, \& Song, 2013). Ethnocentric consumers exhibit a preference for domestic brands (Kumar et al., 2013). However, consumer ethnocentrism does not always lead to a favorable attitude towards local products or willingness to purchase local products. For instance, studies (Mangnale, Potluri, \& Degufu, 2011; Mensah, Bahhouth, \& Ziemnowicz, 2011; Ranjbarian et al., 2010; Bahaee \& Pisani, 2009) have shown that despite the sense of ethnocentrism shown by some consumers in developing countries, they do not appear to be highly ethnocentric. As a result, they do not display highly favorable attitudes towards local products. Therefore, there is reverse ethnocentrism in developing countries (Agbonifoh \& Elimimian, 1999). Consequent to consumer ethnocentrism irregular link with attitudes towards local products, we argue that consumer ethnocentrism may not adequately trigger favorable attitude towards purchase intention for local brand automobiles manufactured locally without consideration to consumers' central issues. Hence, consumers are believed to ponder over issues that relate to their survival and happiness prior to attitudinal decisions. While Agbonifoh and Elimimian (1999) maintained that consumers in developing countries display reverse ethnocentrism, we contend that consumer ethnocentrism in developing countries will transform into favorable consumer attitudes towards purchase intention for local brand automobiles manufactured locally if consumers' basic needs are prioritized. In addition, consumer ethnocentrism may trigger favorable attitudes towards local brand automobiles when consumers' beliefs such as: ensuring employment of indigenes, and supporting the local economy through consistent tax remittance are upheld by firms.

\subsection{Collectivism and attitudes towards purchase intention for local brand automobiles manufactured locally}

Collectivism is a social form of closely allied people who define themselves as inter-reliant members of a collective group (Vandello \& Cohen, 1999). According to Hofstede (2011), collectivists are inhabitants of a society filled with a perception of "we/our" society. Triandis, Brislin, and Hui (1988) noted that in a collectivistic society, people tend to attain group harmony, even if it means to sacrifice their objectives to remain in their group. "Collectivists perceive themselves as interconnected with their in-groups, mutually obligated to them, and socially embedded in their networks" (Shavitt \& Barnes, 2020). Malaysia is rated high on the collectivism scale of Hofstede's cultural value dimensions (cf. Hofstede-insights). As a result of that, Malaysian consumers are expected to exhibit attitudes that ensure in-group harmony and progress. Absconding from in-group norms (that is: developing a positive attitude towards purchase intention for non-locally manufactured automobiles) which Hofstede (2011) refers to as transgression of norms begets shame. Thus, collectivism is central to a favorable attitude towards purchase intention for local brand automobiles manufactured locally. In line with Hofstede's (2011) arguments, collectivistic consumers' relationships ought to prevail over tasks. Hence, collectivism prompts consumers to be conscious of their attitude 
towards purchase intention for local brand automobiles manufactured locally rather than having a positive attitude towards out-group automobiles (imported autos) that may satisfy their self-interests.

Collectivism influenced Indian consumers' preference for local products (Kumar et al., 2013). Consumers with greater adherence to collectivism are likely to engage in a purchase behavior/ intention due to their positive attitudes (Lobo \& Greenland, 2017). Based on the principles of collectivism, consumers' attitudes towards purchase intention for local brand automobiles manufactured locally are believed to improve because, collectivism is built on "we consciousness" and collectivists would rarely like to be tagged violators of group norms. Shavitt and Barnes (2020) stated that collectivist consumers prioritize actualizing in-group members' prospects, fitting in through making unanimous choices, and cultivating their important associations. Hence, collectivistic consumers are selfless in their temperaments and further display favorable attitudes towards local brand automobiles manufactured locally.

\section{Methodology}

\subsection{Study Approach and Design}

The study employed a quantitative approach. This approach allows the generalization of inferences from the study sample to a larger population (Neuman, 2006; Creswell, 2003), and is expedient in answering the research questions. Also, a crosssectional design was adopted. A cross-sectional design is a research design that allows data collection from a section of the population under study at a specific time and uses it for generalization purposes (Neuman, 2006).

\subsection{Location}

The study was conducted in Klang Valley Malaysia. Malaysia is a fast developing country in South-east Asia with initially two (Proton and Perodua) state-owned automobile manufacturing companies. Malaysia later sold about $49.9 \%$ of Proton shares to a Geely Automobile Holdings in 2017. Three malls (Pavilion shopping mall KL, Mid-valley Mall KL, and Sunway shopping mall) were randomly selected from the seven biggest shopping malls in Klang Valley, Malaysia. Seven biggest malls were considered apt for study location given the seasonal automobile exhibition in big malls in Klang Valley. Moreover, there is a high frequency of customer flow in big malls. This makes data collection within shopping malls suitable for consumer research.

\subsection{Operationalization and measurement of variables}

Attitude towards purchase intention for local brand automobiles manufactured locally: This refers to consumers' positive or negative inclination over the acquisition of automobiles produced within their (consumers') country.

Consumer ethnocentrism: This is consumers' willful dissociation in purchasing products of foreign companies while maintaining their preferences for local products manufactured locally.

Collectivism: Collectivism is the incorporation of different consumers into a particular group with a common goal of protecting the group's economy against foreign business threats.

The main variables (attitude towards purchase intention for local brand automobiles manufactured locally, consumer ethnocentrism, and collectivism) of the study were measured on seven (7) point Likert scale with varying numbers of items. Even though some of the measuring items were originally developed on a 5-point Likert scale, the study adopted 7-point Likert scale to reduce the likelihood of common responses from the respondents. Seven point Likert scale provide more accurate measures of a respondent's true evaluation (Finstad, 2010). Moreover, it enables high variance in a dataset. Attitude towards purchase intention for local brand automobiles manufactured locally was measured with four (4) items adapted from Taylor and Todd (1995), and Kim and Han (2010). Also, consumer ethnocentrism, and collectivism were measured with four (4) items adapted from Shimp and Sharma (1987), and Yoo, Donthu, and Lenartowicz (2011) respectively. This implies that the scores of each variable can range between 4 and 28, with lower scores showing low tendencies of the variables and vice versa. Please refer to the appendix section for the measures. Expectedly, respondents should have a good command of the language used to develop or structure the measuring instruments. The adapted instruments were developed in English language, necessitating translation to Malaysian language. Consequent to the guidelines suggested by Craig and Douglas (2000) for conducting international consumer research, the measuring instruments were translated by two independent bi-lingual translators into Bahasa Melayu (Malaysian language). Thereafter, the translated Bahasa Melayu instruments were back-translated to English language by two different independent bi-lingual translators to ensure conceptual correspondence of measures between the two versions of the questionnaire (Cui, Lui, Chan, \& Joy, 2012; Berry, 1980). It was further cross-checked and validated by three experts.

\subsection{Population, sampling, and data collection}

The population of Proton automobile company consumers in Malaysia has grown to about 3,760,000 (Shah, 2016). Despite a decline in Proton auto sales (Paultan.org, 2018), their market share is believed not to plummet due to recent revamp within the management hierarchy and the introduction of Proton X70. Thus, Proton's potential consumers are believed to be more than the number of consumers $(70,000)$ they had in one of their gloomy market years, 2017. 
The study adopted a systematic sampling technique. Using Cochran (1977) sample size calculation formula: $\mathrm{n}=$ $(t)^{2 *}(p)(q) /(d)^{2}, 385$ Proton potential consumers were expected to participate in the study.

Mall intercept survey was adopted for data collection. Past consumer researchers (such as: Saffu, Walker \& Mazurek, 2010; Jin-Lee, Phau \& Roy, 2013) have validated mall intercept as a robust and reliable means of data collection. Data were collected from every fourth person at strategic entry points of the three malls. Whereby a potential respondent refused to participate, the interval sequence is repeated to get another respondent. In all, about 97\% (373) valid responses were received from Proton's potential consumers.

\subsection{Reliability and normality tests}

The study's main variables' Cronbach alpha ranged between .84 and .90 . According to Hair et al. (2010), an alpha value of .70 is sufficient for research purposes. Predicated on the above, the study instruments are reliable. In terms of the distribution of the dataset, descriptive findings of exploratory data analyses (EDA) were used to determine the multivariate normality of the dataset's distribution. An approximately normally distributed data should have a skewness and kurtosis value obtained within \pm 2.0 cutoff point (Khan, 2015; George \& Mallery, 2010). Relying on that, the study variables' skewness and kurtosis are within the acceptable margin as shown in Table 1. Thus, multivariate normality criteria have been fulfilled. Following the mean scores of between 16.57 and 18.95, it denotes that Proton potential consumers are highly collectivistic, relatively ethnocentric, and exhibit reasonably favorable attitudes towards purchase intention for Proton automobile.

Table 1

Reliability coefficients and EDA descriptive values

\begin{tabular}{cccccccc}
\hline Variables & Cronbach alpha & Skewness & SE & Kurtosis & SE & Mean & SD \\
\hline Attitude & .900 & -.272 & .126 & -.793 & .252 & 18.38 & 5.84 \\
Consumer ethnocentrism & .870 & -.037 & .126 & -.689 & .252 & 16.57 & 5.77 \\
Collectivism & .837 & -.335 & .126 & -.136 & .252 & 18.95 & 4.99 \\
\hline
\end{tabular}

Note: $\mathrm{SE}=$ Standard error; $\mathrm{SD}=$ Standard deviation

\subsection{Data analysis}

Data were analyzed with SPSS version 25. Descriptive statistics were used to describe sample characteristics and to assess potential consumers' attitudes towards purchase intention for local brand automobiles manufactured locally. To determine the predictive effects of two variables on attitude towards purchase intention for local brand automobiles manufactured locally, the prediction was made using the equation: $Y=b_{0}+b_{1} X_{1}+b_{2} X_{2}+b p X p$. Where $Y=D V$ (attitudes towards purchase intention for local brand automobiles manufactured locally);

$\mathrm{X}_{1}, \mathrm{X}_{2}$, = IVs (Consumer ethnocentrism, collectivism)

$\mathrm{b}_{\mathrm{o}}=\mathrm{Y}$-intercept

$\mathrm{b}_{1}, \mathrm{~b}_{2}=$ Regression coefficients

$\mathrm{p}=$ Number of observations

\section{Results and Discussions}

\subsection{Respondents' information}

The respondents' background information has been summarized in Fig. 1. Results depicted that females are slightly more than half $(51.5 \%)$ of the respondents while males are $48.5 \%$. Respondents' age range was categorized into four. Age range 18 to 28 years accounted for the highest (56.3\%) proportion of respondents, covering more than half of the total sample (373). This was followed by 29 to 39 years age range $(27.6 \%)$, and 40 to 50 years age range $(12.6 \%)$, with age range 51 to 60 years covering the least $(3.5 \%)$ proportion of respondents. With age mean 30.94 , it indicates that most of the respondents were averagely young.

In terms of educational level, more than half $(68.1 \%)$ of the respondents attained tertiary educational level. A good proportion $(27.9 \%)$ of them had secondary education, while $2.7 \%$ acquired primary education. It is commendable that only $1.3 \%$ of the respondents never attended school. Also, respondents' monthly income was categorized into four, namely: less than minimum wage, minimum wage to RM3487, RM3488 to RM5667, and more than RM5667. The minimum wage is pegged at RM1200 in Malaysia (The Star, 2020). Respondents that make between minimum wage and RM3487 accounted for the highest proportion $(41.3 \%)$. This was followed by the category that receives less than minimum wage $(30.8 \%)$, and the category that earns between RM3488 and Rm5667 which comprised $15.5 \%$ of the respondents. It is surprising that respondents' category that make more than RM5667 made up $12.3 \%$ of the overall sample. Given the estimated monthly income mean of RM2700, it is concluded that the study respondents are relatively low-income earners. 


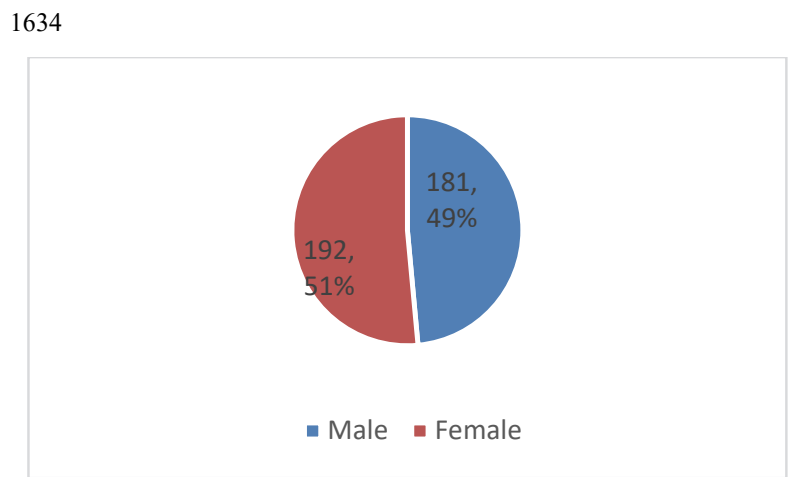

Gender

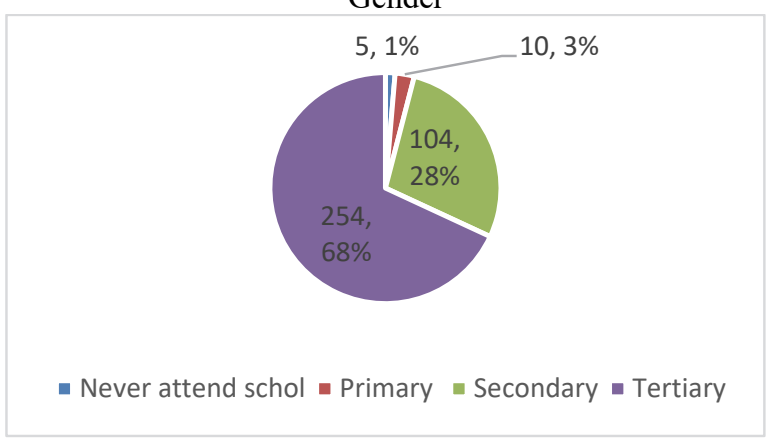

Educational background

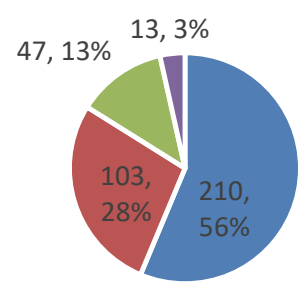

- 18--28 - 29--39 - 40--50 - 51--60

Age $(\max =58, \operatorname{Min}=18$, Mean $=30.94, \mathrm{SD}=9.46)$

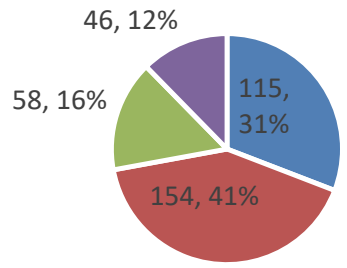

- Mininum wage " MW to 3487 - $3488-5667$ - $>5667$

Income $(\max =8000$, Min $=-$, Mean $=2700, S D=1901)$

Fig. 1. Samples' Characteristics $(n=373)$

Note: Freq. $=$ Frequency; $\%=$ Percentage; $\mathrm{SD}=$ Standard deviation; RM= Ringgit Malaysia, Malaysia's local currency; Atten. $=$ attended; Sch.= School; Inst.= Institution; MW= Minimum wage.

\subsection{Attitudinal tendencies of Proton potential consumers}

Tabulated results of attitudinal statements of Proton's potential consumers in Table 3 indicated that Proton's potential consumers' responses were more favorable to the first attitudinal statement. Inspection of the response proportion depict that the first statement did not only have the highest percentage of strongly agree (17.2\%) and agree (24.7\%) responses, it also had the smallest percentage of strongly disagree (2.7\%). This was followed by the second statement with $13.4 \%$ strongly agree and $22.5 \%$ agree responses, cum 3.5\% strongly disagree. On the other hand, Proton's potential consumers' responses towards the third statement were the least favorable. Despite having the least percentage $(12.6 \%)$ of strongly agree and somewhat agree (16.9\%), it exhibited the highest percentage (10.2) of disagree. Accordingly, these results generally indicate a favorable attitude towards purchase intention for Proton automobiles. It is an indication of attitudinal attributes that spur consumers towards local brand products manufactured locally. Additionally, it depicted the importance of proximity and accessibility to consumers which is an edge to local companies against foreign firms. Also, Proton potential consumers' attitudes may go either way (favorable/unfavorable) in the face of comparison between imported autos in the same category. The second statement echoed the relevance of functionality/usefulness of Proton automobiles to potential consumers. While potential consumers' attitudes towards Proton automobiles desire functional autos for guaranteed favorable attitudes towards purchase intention, it became clearer in the third statement that they consider features that ensure pleasure in Proton autos. Thus, it was the reason for their least favorable response towards attitudinal statements. Lastly, responses to the fourth statement indicated the importance of assurance or certainty in Proton automobile performance. Relying on the result, it is stated that a more favorable attitude towards purchase intention will be shown to Proton automobiles if Proton company establishes more product performance assurances.

Table 2

Tabulated attitudinal statements with response ratios

\begin{tabular}{|c|c|c|c|c|c|c|c|}
\hline $\mathbf{n}$ & $\begin{array}{c}\text { Strongly } \\
\text { Disagree } \\
\%\end{array}$ & Disagree & $\begin{array}{c}\text { Somewhat } \\
\text { Disagree } \\
\%\end{array}$ & Neutral & $\begin{array}{c}\text { Somewhat } \\
\text { agree } \\
\%\end{array}$ & Agree & $\begin{array}{l}\text { Strongly } \\
\text { agree } \\
\%\end{array}$ \\
\hline \multicolumn{8}{|c|}{ I am in favor of purchasing Proton automobile because their showrooms are easily found. } \\
\hline 373 & 2.7 & 6.4 & 12.1 & 16.9 & 20.1 & 24.7 & 17.2 \\
\hline \multicolumn{8}{|c|}{ Purchasing Proton automobile is desirable because it offers better quality than imported autos within the same category. } \\
\hline 373 & 3.5 & 7.8 & 12.6 & 22.0 & 18.2 & 22.5 & 13.4 \\
\hline \multicolumn{8}{|c|}{$\begin{array}{l}\text { Given a choice between imported and locally manufactured automobiles, I will still choose Proton automobile because it is an enjoyable mode of trans- } \\
\text { portation. }\end{array}$} \\
\hline 373 & 5.4 & 10.2 & 15.3 & 20.9 & 16.9 & 18.8 & 12.6 \\
\hline \multicolumn{8}{|c|}{ Any time I need a new automobile, my first choice of vehicle will be Proton automobile because it gives confidence. } \\
\hline 373 & 5.6 & 9.4 & 14.2 & 20.6 & 18.8 & 18.0 & 13.4 \\
\hline
\end{tabular}


4.3 Predictive effects of consumer ethnocentrism and collectivism on attitude towards purchase intention for local brand automobiles manufactured locally

Standard multiple regression was used to accurately assess the ability of two variables (consumer ethnocentrism, and collectivism) to predict attitude towards purchase intention for local brand automobiles manufactured locally. Preliminary analyses were conducted to ensure no violation of the assumptions of normality, linearity, multicollinearity, and homoscedasticity. The model was statistically significant $F(2,370)=88.64, p<.001$ and explained $32.4 \%$ variance in attitude towards purchase intention for local brand automobiles manufactured locally. As depicted in Table 3, the two variables were statistically significant, with consumer ethnocentrism $(\beta=.41, p<.001)$ contributing higher than collectivism $(\beta=.25, p<.001)$. The significant predictive effect of consumer ethnocentrism on attitude towards purchase intention for local brand automobiles manufactured locally is consistent with previous studies of Yildiz et al. (2018); Shu, Strombeck, and Hsieh (2013); and Kumar et al. (2011). The result implies that a favorable attitude towards purchase intention for local brand automobiles manufactured locally is positively reliant on consumer ethnocentrism among others. It also signifies that the more ethnocentric consumers are, the more favorable their attitudes towards purchase intention for local brand automobiles manufactured locally. In line with the moral foundation theory (MFT), consumers become ethnocentric as a precautionary measure to adaptive challenges and current triggers such as market globalization. Consumers use their ethnocentric tendencies to demonstrate care and loyalty towards indigenous companies. More so, the significant predictive effect of collectivism on attitude towards purchase intention for local brand automobiles manufactured locally is in tandem with past studies of Kumar et al. (2013), and Schrank and Running (2016). While Kumar et al. (2013) found that collectivism influences preference for local brand products and mobile services, Schrank and Running (2016) noted that consumers' attitudes towards local organic food are influenced by collectivism. In essence, the results depicted that both consumer ethnocentrism and collectivism are instrumental in ensuring favorable consumer attitudes. Graham et al. (2013) noted that those whose minds are organized in advance before experience of negative interpersonal relational outcomes are never shortchanged in a competition. Collectivism equips consumers against unnecessary flooding of their market/environment with products that do not augur well with their beliefs. In consumers' bid to secure their environment/society, they form an alliance in advance against unnecessary competition that tends to make their locality a dumping ground, and collectively support local companies due to their beliefs.

Table 3

Summarized results of multiple regression

\begin{tabular}{ccccccc}
\hline Variables & Unstandardized beta & Standard error & Beta & $\boldsymbol{t}$ & $\boldsymbol{P}$ & VIF \\
\hline Constant & 5.883 & 1.035 & & 5.683 & .000 & \\
Cons. Ethno & .414 & .048 & .408 & 8.550 & $<.001$ & 1.248 \\
Collectivism & .298 & .056 & .254 & 5.322 & $<.001$ & 1.248 \\
\hline
\end{tabular}

$\mathrm{R}^{2}=.324 ;$ Adjusted $\mathrm{R}^{2}=.320 ; \quad F=88.641$

Note: The dependent variable was attitude towards purchase intention; Cons. Ethno= Consumer ethnocentrism; $t=t$-statistics; $P=$ Probability power, significant at $0.05 ; \mathrm{VIF}=$ variance inflation factor

\subsection{Conclusion and limitations}

Given the increasing level of market globalization and its deleterious effects on local economies, moral foundation theory (MFT) was employed to explain the essence of exhibiting favorable attitudes towards purchase intention for local brand automobiles manufactured locally. By exploring three out of the five dimensions of MFT, it was concluded that consumer ethnocentrism and collectivism are symbols of care, loyalty, and sanctity. When consumers perceive deceptive social exchange in the form of market globalization, they display high ethnocentric emotions as a sign of care and loyalty to their government and local manufacturing companies. In consumers' bid to secure their environment/society, they form alliances in advance against unnecessary competition that tend to make their locality a dumping ground and collectively support local companies as a result of their beliefs. The study also elucidated that Proton potential consumers' attitudes towards purchase intention for Proton automobiles were favorable. Additionally, the significant predictive effects of consumer ethnocentrism and collectivism on attitude towards purchase intention for Proton automobiles were ascertained. Our findings validated MFT in explaining consumers' attitudes towards purchase intention for local brand automobiles manufactured locally. Thus, MFT demonstrated that consumer attitude is either learned or displayed based on certain moral grounds. Concerning Proton potential consumers' attitudinal tendencies, the study concludes that without closeness and accessibility of Proton showrooms, good automobile (Proton) quality compared to imported ones of its class, and enjoyable features in Proton autos, intensified favorable attitudes towards purchase intention for Proton automobiles may be far from realization. Furthermore, Proton automobile company ought to invest in the cultivation of ethnocentric and collectivistic feelings in potential consumers for sustained favorable attitudes towards purchase intention for Proton automobiles. More so, the study implies that as an emerging economy, Malaysia's dream of being a developed nation is not farfetched given Proton potential consumers' demonstration of favorable attitudes towards purchase intention for Proton automobiles. Moreover, this study supports and adds to the existing literatures that seek to understand consumer attitudes towards purchase intention for local products manufactured locally in developing countries. It further shows that contrary to the perceptions of some scholars (such as: Bahaee \& Pisani, 2009, Agbonifoh \& Elimimian, 1999) on consumer ethnocentrism in developing countries, local consumers tend to be ethnocentric based on their cultural beliefs. Hence, consumers from collectivistic societies are ethnocentric irrespective of their countries' economic or technological standings and further display favorable attitudes towards purchase intention for local products 
manufactured locally. The study concludes that Malaysian consumers are both ethnocentric, collectivists, and demonstrate favorable attitudes towards local brand automobiles manufactured locally.

The limitation of this study is mainly on the use of Proton potential consumers to assess attitude towards purchase intention for local brand automobiles manufactured in Malaysia. The existence of another automobile manufacturing company (Perodua) owned by the state may have influenced the views of potential consumers of local brand automobiles. This may have influenced responses from the respondents. Hence, generalization of the findings should be done cautiously. Furthermore, the model lacks some variables that could have improved the explained variance in attitudes towards purchase intention for local brand automobiles manufactured locally. Therefore, future studies should sample State-owned automobile firms to eliminate bias among potential consumers. In line with the study's regression sum of squares result, it is necessary to explore the unexplained variance $(67.6 \%)$ because the residual mean square was greater than the regression mean square. Thus, more predictors (independent variables) such as product quality, showroom proximity, and accessibility should be added to enhance variance explanation in attitude towards purchase intention for local brand automobiles manufactured locally.

\section{References}

Agbonifoh, B. A., \& Elimimian, J. U. (1999). Attitudes of developing countries towards country-of-origin products in an era of multiple brands. Journal of International Consumer Marketing, 11(4), 97-116.

Ajzen, I. (1991). The theory of planned behavior. Organizational Behavior and Human Decision Processes, 50(2), $179-211$.

Bahaee, M., \& Pisani, M. J. (2009). Are Iranian consumers poised to buy American in a hostile bilateral environment? Business Horizons, 52(3), 223-232.

Becic, M. (2017). An assessment of consumer ethnocentrism tendencies scale among university students: The case of Turkish and Bosnian student Inquiry. Sarajevo Journal of Society Sciences, 2(1), 119-130.

Berry, J. W. (1980). Introduction to methodology. in Triandis, H.C. and Berry, J.W. (Eds), The Handbook of Cross-cultural Psychology, Vol. 2, Allyn and Bacon, Boston, MA, pp. 1-29.

Bilkey, W. J., \& Nes, E. (1982). Country-of-origin effects on product evaluations. Journal of International Business Studies, 13(1), 89-99.

Chinedu, A. H., Haron, S. A., Hashim, A, H., \& Ho, J. A. (2020). Consumers’ Attitudes Towards Locally Manufactured High Involvement Products: A Systematic Review. Asian Social Science, 16(12), pp. 80-92.

Cicic, M., Brkic, N., \& Praso-Krupalija, M. (2003). Consumer animosity and ethnocentrism in Bosnia and Herzegovina: the case of a developing country in a post-ware time. Akademija MM-Slovenian Marketing Research Journal, 6(10), 59-73.

Cochran, W. G. (1977). Sampling techniques (3rd ed.). New York: John Wiley and Sons.

Correa, S., \& Parente-Laverde, A.-M. (2017). Consumer Ethnocentrism, Country Image and Local Brand Preference: The Case of the Colombian Textile, Apparel and Leather Industry. Global Business Review, 18(5), 1111-1123.

Craig, C. S., \& Douglas, S. P. (2000), International Marketing Research, 2nd ed., Wiley, New York, NY.

Creswell, J. W. (2003). Research design: qualitative, quantitative, and mixed approaches (2nd Ed.). Thousand Oaks, CA: Sage Publications, Inc.

Cui, G., Lui, H., Chan, T., \& Joy, A. (2012). Decomposition of cross-country differences in consumer attitudes toward marketing. Journal of Consumer Marketing, 29(3), 214-224. Doi:10.1108/07363761211221747.

De Waal, F. (1982). Chimpanzee politics: Power and sex among apes. London: Jonathan Cape.

Dunbar, R. (1996). Grooming, gossip, and the evolution of language. Cambridge, MA: Harvard University Press.

Fazio, R. H., Powell, M. C., \& William, C. J. (1989). The role of attitude accessibility in the attitude-to-behavior process. Journal of Consumer Research, 16(3), 280-8.

Finstad, K. (2010). Response Interpolation and Scale Sensitivity: Evidence against 5-Point Scales. Journal of Usability Studies, 5(3), pp. 104-110.

Fishbein, M., \& Ajzen, I (1975). Belief, Attitude, Intention, and Behavior: An Introduction to Theory and Research. AddisonWesley Publishing Co., Reading, MA: Addison-Wesley Pub Co.

Fiske, A. P. (1991). Structures of social life: The four elementary forms of human relations: Communal sharing, authority ranking, equality matching, market pricing. New York: Free Press.

George, D., \& Mallery, M. (2010). SPSS for Windows Step by Step: A Simple Guide and Reference, 17.0 update, $10^{\text {th }}$ ed. Boston: Pearson.

Graham, J., Haidt, J., Koleva, S., Motyl, M., Iyer, R., Wojcik, S. P., \& Ditto, P. H. (2013). Moral Foundations Theory. Advances in Experimental Social Psychology, pp. 55-130. Doi:10.1016/b978-0-12-407236-7.00002-4.

Haidt, J. (2012). The righteous mind: Why good people are divided by politics and religion. New York: Pantheon.

Hair, J. F., Black, W. C., Babin, B. J., \& Anderson, R. E. (2010). Multivariate data analysis, $7^{\text {th }}$ ed. Upper saddle River NJ, Pearson Prentice Hall.

Hofstede, G. (2011). Dimensionalizing Cultures: The Hofstede Model in Context. Online Readings in Psychology and Culture, 2(1). doi:10.9707/2307-0919.1014.

Hofstede-Insights. COMPARE COUNTRIES. Available at: https:/www.hofstede-insights.com/product/compare-countries/.

Jin Lee, W., Phau, I., \& Roy, R. (2013). "Bonds" or “Calvin Klein” Down-under. Journal of Fashion Marketing and Management: An International Journal, 17(1), 65-84. Doi:10.1108/13612021311305146. 
John, A. V., \& Brady, M. P. (2011). Consumer ethnocentrism and attitudes toward South African consumables in Mozambique. African Journal of Economic and Management Studies, 2(1), pp. 72-93.

Karoui, S., \& Khemakhem, R. (2019). Consumer ethnocentrism in developing countries. European Research on Management and Business Economics, 25(2), pp. 63-71. Doi:10.1016/j.iedeen.2019.04.002.

Khan, A. F. (2015). Assessment of Midlife career Stress on Indian Managers. Ph.D Thesis. Aligarh Muslim University.

Kim, Y., \& Han, H. (2010). Intention to pay conventional-hotel prices at a green hotel - a modification of the theory of planned behavior. Journal of Sustainable Tourism, 18(8), 997-1014. doi:10.1080/09669582.2010.490300.

Klein, J. G., Ettenson, R., \& Krishnan, B. C. (2006). Extending the construct of consumer ethnocentrism: when foreign products are preferred. International Marketing Review, 23(3), pp. 304-21.

Kumar, A., Fairhurst, A., \& Kim, Y.-K. (2011). Ethnocentric tendencies of Indian consumers: Impact on preference for domestic versus foreign products. The International Review of Retail, Distribution and Consumer Research, 21 (4), $323-341$.

Kumar, A., Fairhurst, A., \& Kim, Y.-K. (2013). The role of personal cultural orientation in consumer ethnocentrism among Indian consumers. Journal of Indian Business Research, 5(4), pp. 235-250. doi:10.1108/jibr-02-2013-0018.

Lantz, G. \& Loeb, S. (1996). Country of origin and ethnocentrism: an analysis of Canadian and American preferences using social identity theory. Advances in Consumer Research, 23, 374-378.

Lobo, A., \& Greenland, S. (2017). The influence of cultural values on green purchase behaviour. Marketing Intelligence \& Planning, 35(3), 377-396

Lotz, S. L., \& Hu, M. Y. (2001). Diluting negative country of origin stereotypes: a social stereotype approach. Journal of Marketing Management, 17(1/2),105-35.

Mangnale, V. S., Potluri, R. M., \& Degufu, H. (2011). A study on ethnocentric tendencies of Ethiopian consumers. Asian Journal of Business Management, 3(4), 241-250.

Makanyeza, C. (2014). Measuring Consumer Attitude towards Imported Poultry Meat Products in a Developing Market: An Assessment of Reliability, Validity and Dimensionality of the Tri-Component Attitude Model. Mediterranean Journal of Social Sciences, 5(20), 874-881. Doi:10.5901/mjss.2014.v5n20p874.

Makanyeza, C., \& Du Toit, F. (2017). Consumer ethnocentrism in developing countries: Application of a model in Zimbabwe. Acta Commercii, 17(1), 1-9.

Mensah, E. C., Bahhouth, V., \& Ziemnowicz, C. (2011). Ethnocentrism and purchase decisions among Ghanaian consumers. Journal of Applied Business and Economics, 12(4), pp. 20-25.

Neuman, W. L. (2006). Social research methods: Qualitative and quantitative approaches (6 $6^{\text {th }}$ ed.) Boston: Allyn and Beacon.

Oaten, M., Stevenson, R. J., \& Case, T. I. (2009). Disgust as a disease avoidance mechanism. Psychological Bulletin, 135, pp. 303-321.

Paultan.org (2018). Proton records 70,991 units sold in 2017, down 1.8\%. Available at: https://paultan.org/2018/01/08/protonsales-result-end-2017/.

Perner, L. (2010). Consumer behavior: the psychology of marketing. Available at: http://www.consumerpsychologist.com/.

Ranjbarian, B., Morteza, R., \& Mirzaei, A. (2010). Consumer ethnocentrism and buying intentions: An empirical analysis of Iranian consumers. European Journal of Social Sciences, 13(3), 371-386.

Saffu, K., Walker, J.H. and Mazurek, M. (2010). The role of consumer ethnocentrism in a buy national campaign in a transitioning country: Some evidence from Slovakia. International Journal of Emerging Markets, 5(2), pp. 203-226.

Samiee, S. (1994). Customer evaluation of products in a global market. Journal of International Business Studies, 25(3), 579604.

Samoui, F. (2009). Effet de l'origine perçue du nom de marque sur les perceptions du consommateur: cas du consommateur de pays emergents 8 th international congress marketing trends, Paris (2009), p. 27

Schrank, Z., \& Running, K. (2016). Individualist and collectivist consumer motivations in local organic food markets. Journal of Consumer Culture, 18(1), pp. 184-201.

Shavitt, S., \& Barnes, A. J. (2020). Culture and the consumer journey. Journal of Retailing, 96(1), pp. 40-54.

Shimp, T. A. (1984). Consumer ethnocentrism: The concept and a preliminary empirical test. Association for Consumer Research, 11, 285-290.

Shimp, T. A., \& Sharma, S. (1987). Consumer ethnocentrism: Construction and validation of the CETSCALE. Journal of Marketing Research, 24(3), 280-289.

Shu, S. T., Strombeck, S., \& Hsieh, C. L. (2013). Consumer ethnocentrism, self-image congruence and local brand preference: A cross-national examination. Asia Pacific Management Review, 18(1), 43-61.

Sreen, N., Purbey, S., \& Sadarangani, P. (2018). Impact of culture, behavior and gender on green purchase intention. Journal of Retailing and Consumer Services, 41, 177-189.

Stenner, K. (2005). The authoritarian dynamic. New York: Cambridge

Sumner, G. A. (1906). Folkways: A Study of the Sociological Importance of Usages, Manners, Customs, Mores and Morals, Wiley, New York, NY.

Taylor, S., \& Todd, P. (1995). An Integrated Model of Waste Management Behavior. Environment and Behavior, 27(5), 603630. Doi:10.1177/0013916595275001.

Teo, P.C., Mohamad, O., \& Ramayah, T. (2011). Testing the dimensionality of Consumer Ethnocentrism Scale (CETSCALE) among a young Malaysian consumer market segment. African Journal of Business Management, 5(7), $2805-2816$.

The Star (2020). New minimum wage gazette. Available at: https://www.thestar.com.my/news/nation/2020/01/14/new-minimum-wage-gazetted. 
Triandis, H. C., Brislin, R., \& Hui, C. H. (1988). Cross-cultural training across the individualism-collectivism divide. International Journal of Intercultural Relations, 12(3), 269-289.

Trivers, R. L. (1971). The evolution of reciprocal altruism. The Quarterly Review of Biology, 46, 35-57.

Tsai, W. H., Lee, W. N., \& Song, Y. A. (2013). A cross-cultural study of consumer ethnocentrism between China and the U.S. Journal of International Consumer Marketing, 25(2), 80-93.

Vandello, J. A., \& Cohen, D. (1999). Patterns of individualism and collectivism across the United States. Journal of Personality and Social Psychology, 77(2), pp. 279-286.

Verlegh, P. W. J., Jan-Benedict, E., \& Steenkamp, M. (1997). Country-of-origin effects - A meta-analytic review Paper presented at marketing: Progress, prospects, perspectives, Warwick Business School UK, pp. 2136-2140.

Vida, I., \& Fairhurst, A. (1999). Factors underlying the phenomenon of consumer ethnocentricity: Evidence from four central European countries. The International Review of Retail, Distribution and Consumer Research, 9(4), 321-337.

Vida, I., Dmitrovic, T., \& Obadia, C. (2008). The role of ethnic affiliation in consumer ethnocentrism. European Journal of Marketing, 42(3/4), pp. 327-43.

Vijayakumar, V., \& Brezinova, O. (2012). An empirical study on visibility of conspicuous consumption motives of consumers in Jaffna, Sri Lanka. International Journal of Trade Economics and Finance, 3(3), 239-244.

Yildiz, H., Heitz-Spahn, S., \& Belaud, L. (2018). Do ethnocentric consumers really buy local products? Journal of Retailing and Consumer Services, 43, 139-148.

Yoo, B., Donthu, N., \& Lenartowicz, T. (2011). Measuring Hofstede's Five Dimensions of Cultural Values at the Individual Level: Development and Validation of CVSCALE. Journal of International Consumer Marketing, 23(3), $193-210$.

\section{Appendix}

\section{Instruments: Attitude}

(i) I am in favor of purchasing Proton automobile because their showrooms are easily found.

Saya memilih untuk membeli kereta Proton kerana bilik pameran mereka mudah di dapati.

(ii) Purchasing Proton automobile is desirable because it offers better quality than imported autos within the same category.

Membeli kereta Proton adalah wajar kerana ia menawarkan kualiti yang lebih baik daripada kereta diimport dalam kategori yang sama.

(iii) Given a choice between imported and locally manufactured automobiles, I will still choose Proton automobile because it is an enjoyable mode of transportation.

Jika diberi pilihan antara kereta import dan tempatan, saya masih akan memilih kereta Proston kerana ia merupakan kaedah pengangkutan yang menyeronokkan.

(iv) Any time I need a new automobile, my first choice of vehicle will be Proton automobile because it gives confidence. Pada bila-bila masa saya memerlukan sebuah kereta baru, pilihan pertama kenderaan saya akan tetap kereta Proton kerana ia memberikan saya keyakinan.

\section{Consumer ethnocentrism}

(i) It is not right to purchase foreign automobiles because it puts Malaysians out of job.

Adalah tidak betul membeli kereta buatan negara luar kerana ia boleh mengakibatkan rakyat Malaysia hilang pekerjaan.

(ii) As a real Malaysian, I should always buy local brand automobiles manufactured locally.

Sebagai rakyat jati Malaysia, saya mestilah sentiasa membeli kereta jenama tempatan yang dihasilkan di dalam negara.

(iii) I will purchase local brand automobiles manufactured locally instead of letting other countries get rich off us.

Saya akan membeli kereta jenama tempatan yang dibuat secara tempatan dan bukannya membiarkan negara-negara lain menjadi kaya.

(iv) As a Malaysian, I shouldn't buy foreign automobiles because it hurts local businesses or causes unemployment.

Sebagai rakyat Malaysia, saya tidak patut membeli kereta negara luar kerana ia menjejaskan perniagaan tempatan atau menyebabkan pengangguran.

\section{Collectivism}

(i) I will remain in my group even in difficult times.

Saya akan kekal dalam kumpulan saya walaupun dalam masa yang sukar.

(ii) The welfare of my cultural group is more important to me than personal gains.

Kebajikan kumpulan budaya saya adalah lebih penting berbanding keuntungan peribadi.

(iii) Working hard for the success of my group is more important than personal success.

Bekerja keras untuk kejayaan kumpulan saya adalah lebih penting berbanding kejayaan peribadi.

(iv) People should only pursue their goals after considering the welfare of the group.

Seseorang perlu mengejar matlamat sendiri hanya selepas mempertimbangkan kebajikan kumpulan.

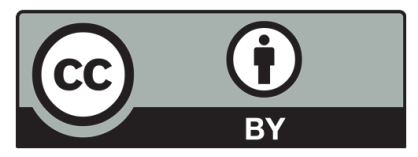

(C) 2021 by the authors; licensee Growing Science, Canada. This is an open access article distributed under the terms and conditions of the Creative Commons Attribution (CC-BY) license (http://creativecommons.org/licenses/by/4.0/). 